\title{
A SUSTAINABLE APPROACH TO THE CONSTRUCTION OF COASTAL FACILITIES THROUGH THE INCORPORATION OF BEACH SAND \& BRACKISH WATER IN CONCRETE PRODUCTION
}

\author{
Imran H.R. Khan ${ }^{1 *}$, Daniel L. White ${ }^{2}$ and Jenelle Mieux ${ }^{3}$ \\ ${ }^{1,2}$ Foundations \& Prior Learning - Physics Unit, The University of Trinidad \& Tobago \\ ${ }^{3}$ Project Management and Civil Infrastructure Systems, The University of Trinidad \& Tobago \\ ${ }^{1}$ Email: imran.hayden-khan@utt.edu.tt*(Corresponding author) \\ ${ }^{2}$ Email: daniel.white@utt.edu.tt \\ ${ }^{3}$ Email: jenellemieux@yahoo.com
}

\begin{abstract}
Advances in reinforcement technology has facilitated the transition from traditional steel rebar to non-metallic rebar in reinforced concretes. Consequently, chloride content can be dramatically increased without worry for the deterioration of the encased reinforcement in reinforced concretes that utilizes composite rebar and polymeric/ceramic fibres. The production of one tonne of concrete releases $900 \mathrm{~kg}$ of $\mathrm{CO}_{2}$ emissions. Reductions in $\mathrm{CO}_{2}$ emissions from concrete production can be achieved through the production of 'greener' cements, and utilization of localized aggregate sources. Construction of structures along the coastline provides a unique opportunity for the utilization of beach-sand and brackish water that together can improve the sustainability prospects for construction in these environments. The incorporation into concrete of beach-sand that has been previously excavated is a simple means of reducing reliance on traditional sources of fine aggregate for concrete production. Additionally, the use of brackish water from a nearby estuary has the added benefit of reducing the requirement for potable water. Compressive strength tests were conducted on twenty-two (22) groups of specimens at 7-days, 28days and 42-days. Water-to-cement ratios (w:c) of 0.37, 0.39, 0.43 and 0.45 were employed. Analysis showed that at 0.37 w:c, batches that utilized beach-sand and brackish water, beachsand and potable water, concreting-sand and brackish water were comparable to those produced with concreting-sand and potable water at about $40 M P a$.
\end{abstract}

Keywords: Beach-sand, Brackish water, Concrete, Sustainability

https://doi.org/10.47412/OHYP1809

\section{Introduction}

Anthropogenic climate change is a scientific fact, though its denial in many quarters has garnered support. Ignoring it will have devastating ecological, climatic and socioeconomic consequences. Tackling climate change, through the reduction in carbon dioxide emissions is one of the main aims of the Paris Agreement of 2016. Cement production accounts for about $7 \%$ of global $\mathrm{CO}_{2}$ emissions, with between 600 and $1200 \mathrm{~kg}$ of $\mathrm{CO}_{2}$ being produced per tonne of cement. The global average of $\mathrm{CO}_{2}$ emissions is $900 \mathrm{~kg}$ per tonne of cement produced [1 - 4]. The $\mathrm{CO}_{2}$ emitted by potable water production and pumping, and from mining for aggregate are generally ignored in the calculations for the $\mathrm{CO}_{2}$ emissions of concrete. Consequently, the embodied carbon dioxide in concrete is calculated at between $100 \mathrm{~kg}$ to $300 \mathrm{~kg}$ per cubic metre of concrete based on the cement content [2]. 
The greater green credentials of utilizing onsite fine aggregate and brackish water are the reduced demand for fine aggregate and the associated environmental degradation of mining, and the increased availability of potable water for human consumption [5]. Additionally, the desalination process consumes between 0.4 to $6.7 \mathrm{~kg} \mathrm{CO}_{2}$ per cubic metre of water produced from seawater and 0.4 to $2.5 \mathrm{~kg} \mathrm{CO}_{2}$ per cubic metre of water produced from brackish water, thus the use of brackish water largely eliminates the need for that process in areas where desalination is employed [6]. Trinidad and Tobago is one of the seven (7) Caribbean nations that are considered to have extremely high levels of water stress by the World Resources Institute [7]. Consequently, regions that experience either or both water and energy shortages can benefit from this approach.

The durability of reinforced concrete exposed to marine environments is dependent on the materials used, and the proximity to and exposure time to aggressive elements [8]. The concrete and the reinforcement react differently, but the combined effect can lead to expensive damage to coastal structures [9]. Concrete immersed in seawater is subjected simultaneously to several degradation processes, including:

- The chemical action of the sea salts,

- Wetting and drying in the tidal zones and just above and,

- Abrasion from waves and water-borne sediment.

Concrete that is permanently immersed in seawater can have excellent durability as the presence of $\mathrm{Cl}^{-}$ions increase the solubility of gypsum and ettringite, thus minimizing their expansive effects. Additionally, the reaction products of magnesium sulphate attack and carbonation, brucite and aragonite respectively, reduce the permeability of the concrete by blocking pores [10]. The buildup of salt on concrete that is exposed to wetting and drying cycles can contribute to salt weathering, and negatively impact the durability of the concrete and the embedded steel reinforcement. However, the general consensus is that best durability is achieved with water to cement ratios of about 0.40 to 0.45 with a minimum cement content of $400 \mathrm{~kg} / \mathrm{m}^{3}$ [11].

Chloride ions $\left(\mathrm{Cl}^{-}\right)$in salt and brackish water can penetrate the concrete, initiating and accelerating the deterioration of steel rebar reinforcement, by first destroying the passivity of the steel and then accelerating the corrosion process [12]. The corrosion product thus formed is volumetrically greater than the steel it was derived from by a factor of 2 or 3 . This in turn results in spalling or flaking off of large chunks of concrete, which consequently leaves more of the reinforcement exposed to further deterioration [13]. For such environments, the steel rebars can be epoxy coated or replaced with stainless steel rebars. Additionally, traditionally steel reinforcement is losing market share to newer fibre reinforced polymer (FRP) rebar that are competitively priced with epoxy coated steel rebars. Guidelines for the use of FRP in bridge construction is included in both the Canadian highway bridge code and the American Association of State Highway and Transportation Officials (AASHTO) specifications. The effect of salt on concrete is dependent on exposure type. The American Concrete Institute (ACI) has setup the ACI 440 committee on FiberReinforced Polymer Reinforcement. The five (5) major goals of the subcommittee are to:

- Report on materials research and practices within the FRP industry,

- Develop standards and specifications for industry practitioners, 
- Educate industry stakeholders, through seminars, symposiums and technical sessions,

- Involve students in design competitions that utilise FRP composites,

- Be a forum for the exchange of technical information on the use of FRP composite in reinforced concrete and masonry [14].

The utilization of saltwater in the production of concrete has yielded varying and conflicting results, with authors reporting increased setting times and reduced compressive strength by up to $8 \%$ [15 - 18]. Other authors have reported that the incorporation of pozzolanic materials can counteract the effects of saltwater used as mix water in concrete [19]. Whilst others conclude that saltwater is unsuitable for use in the production of concrete [20]. Consequently, the results obtained and conclusions drawn by the respective authors can be seen as specific to the chemistry of the constituents of the concrete, especially the source of the water.

Locally, concreting sand is mined from alluvial deposits, which are a depleting, non-renewable natural resource. Globally, the civil engineering and construction sector are facing reducing supplies and rising cost [21]. Substitution of beach sand for alluvial sand is a proposition with global interest as researchers lay the ground work to prepare for a future where this can become a reality. The constant action of the waves on beach sand removes much of the silt and clay that can be detrimental to strength development in concrete. Reduction of chloride content has been attempted to bring beach sand in line with BS 882:1992 limits on the chloride ion content [22]. This standard requires the chloride ion content to be between 0.01 and $0.05 \%$ of the combined mass of the coarse and the fine aggregate for pre-stressed concrete and reinforced concrete respectively [23].

Construction of structures along the coastline of Trinidad and Tobago for business or pleasure, is necessary for national development and for economic activities related to the fisheries industry. A case in point would be a proposal for the reconstruction of the fishing and landing facility at Salybia Bay in North Eastern Trinidad. This is just one of about 65 such facilities dotted along the coastline of the island of Trinidad [24]. The above-mentioned location is adjacent to the Salybia River, and as such has the combination of fine aggregate and brackish water onsite.

\section{Methodology}

\subsection{Testing of the Aggregate}

\subsubsection{Organic Content}

Organic matter content of the fine aggregate was determined by the method prescribed by ASTM C40/C40M-16 [25]. This was used to compare the organic content of alluvial concreting sand to that of the beach sand.

\subsubsection{Sieve Analysis}

Sieve analysis of the fine aggregate was conducted in accordance with ASTM C136 / C136M - 14 [26]. And the results used to calculate the fineness modulus (FM) of the fine aggregates determined. Additionally, the fine aggregates were subjected to ASTM C117-04 [27]. Both coarse and fine aggregates were made to satisfy ASTM C33 grading curves [28]. 


\subsection{Testing of the Water}

The salinity of the water was measured by a self-calibrating handheld salinity meter. Sulphate ion content was assayed with a Hach DR820 Colorimeter according to ASTM D516-16 [29]. An Analytik atomic absorption spectrophotometry (AAS) was used to ascertain the sodium, potassium and magnesium ion contents based on ASTM D3561-16 [30], and ASTM D511-14 respectively [31].

\subsection{Concrete Mix Design}

Twenty-two (22) batches of concrete were made according to ACI 211.1 [32] with water to cement ratios of $0.37,0.39,0.41,0.43$, and 0.45 with a slump of 75 to $100 \mathrm{~mm}$ and casted into $150 \mathrm{~mm}$ cylindrical moulds. Specimens were demoulded after 24 hours and water cured and tested after 7 , 28 , and 42 days respectively. The $20 \mathrm{~mm}$ graded coarse aggregate and cement type were held constant, whilst the fine aggregate, mix water, curing water and water to cement ratio varied as shown in Table 2.1. The first letter of the batch designation represents the aggregate $(\mathrm{C}=$ concreting sand, $\mathrm{B}=$ beach sand), the second letter represents the mix water used $(\mathrm{F}=$ fresh water, $\mathrm{B}=$ brackish water $)$, whist the final letter speaks to the curing water $(\mathrm{F}=$ fresh water, $\mathrm{B}=$ brackish water). The number represent the water to cement ratio.

Table 2.1 Batches of concrete utilised with variations in fine aggregate, mix water, curing water and water to cement ratios

\begin{tabular}{|c|c|c|c|c|c|c|c|c|c|c|}
\hline \multicolumn{2}{|c|}{$\begin{array}{c}\text { Standard } \\
\text { Constituents }\end{array}$} & \multicolumn{3}{|c|}{ Variable Constituents } & & \multicolumn{5}{|c|}{ Water to Cement Ratio By Mass } \\
\hline \multirow{9}{*}{ 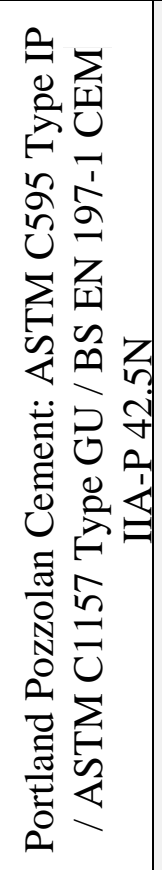 } & \multirow{9}{*}{ 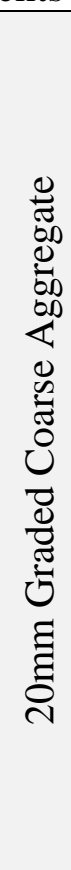 } & $\begin{array}{l}\text { Fine } \\
\text { Aggregate }\end{array}$ & \begin{tabular}{|l|} 
Mix \\
Water
\end{tabular} & $\begin{array}{l}\text { Curing } \\
\text { Water }\end{array}$ & & 0.37 & 0.39 & 0.41 & 0.43 & 0.45 \\
\hline & & $\begin{array}{l}\text { Concreting } \\
\text { Sand }\end{array}$ & \multirow{2}{*}{$\begin{array}{l}\text { Fresh } \\
\text { Water }\end{array}$} & \multirow{4}{*}{$\begin{array}{l}\text { Fresh } \\
\text { Water }\end{array}$} & \multirow{8}{*}{ 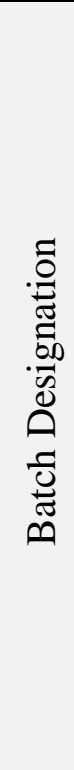 } & CFF37 & CFF39 & CFF41 & CFF43 & CFF45 \\
\hline & & $\begin{array}{l}\text { Beach } \\
\text { Sand }\end{array}$ & & & & - & - & - & - & - \\
\hline & & $\begin{array}{l}\text { Concreting } \\
\text { Sand }\end{array}$ & \multirow{2}{*}{$\begin{array}{l}\text { Brackish } \\
\text { Water }\end{array}$} & & & - & - & - & - & - \\
\hline & & $\begin{array}{l}\text { Beach } \\
\text { Sand }\end{array}$ & & & & - & - & - & - & - \\
\hline & & $\begin{array}{l}\text { Concreting } \\
\text { Sand }\end{array}$ & \multirow{2}{*}{$\begin{array}{l}\text { Fresh } \\
\text { Water }\end{array}$} & \multirow{4}{*}{$\begin{array}{l}\text { Brackish } \\
\text { Water }\end{array}$} & & CFB37 & - & - & - & CFB45 \\
\hline & & $\begin{array}{l}\text { Beach } \\
\text { Sand }\end{array}$ & & & & BFB37 & BFB39 & BFB41 & BFB43 & BFB45 \\
\hline & & $\begin{array}{l}\text { Concreting } \\
\text { Sand }\end{array}$ & \multirow{2}{*}{$\begin{array}{l}\text { Brackish } \\
\text { Water }\end{array}$} & & & CBB37 & CBB39 & CBB41 & CBB43 & CBB45 \\
\hline & & $\begin{array}{l}\text { Beach } \\
\text { Sand }\end{array}$ & & & & BBB37 & BBB39 & BBB41 & BBB43 & BBB45 \\
\hline
\end{tabular}

Table 2.2. The mix proportions per cubic meter of concrete for cement, water, coarse and fine aggregates at the prescribed water to cement ratios 


\begin{tabular}{|l|l|l|l|l|l|l|}
\hline \multicolumn{3}{|c|}{$\begin{array}{l}\text { Proportions Common to } \\
\text { Concreting sand \& Beach sand }\end{array}$} & \multicolumn{2}{c|}{$\begin{array}{l}\text { Concreting Sand } \\
\text { CFF, CFB, and CBB })\end{array}$} & \multicolumn{2}{c|}{$\begin{array}{l}\text { Beach Sand } \\
\text { (BBB, and BFB) }\end{array}$} \\
\hline $\begin{array}{l}\text { Water } \\
\text { to } \\
\begin{array}{l}\text { Cement } \\
\text { Ratio }\end{array}\end{array}$ & $\begin{array}{l}\text { Cement } \\
\left(\mathrm{kg} / \mathrm{m}^{3}\right)\end{array}$ & $\begin{array}{l}\text { Water } \\
\left(1 / \mathrm{m}^{3}\right)\end{array}$ & $\begin{array}{l}\text { Coarse } \\
\text { Aggregate } \\
\left(\mathrm{kg} / \mathrm{m}^{3}\right)\end{array}$ & $\begin{array}{l}\text { Fine } \\
\text { Aggregate } \\
\left(\mathrm{kg} / \mathrm{m}^{3}\right)\end{array}$ & $\begin{array}{l}\text { Coarse } \\
\text { Aggregate } \\
\left(\mathrm{kg} / \mathrm{m}^{3}\right)\end{array}$ & $\begin{array}{l}\text { Fine } \\
\text { Aggregate } \\
\left(\mathrm{kg} / \mathrm{m}^{3}\right)\end{array}$ \\
\hline 0.37 & 501 & 187 & 983 & 731 & 998 & 716 \\
\hline 0.39 & 476 & 187 & 983 & 751 & 998 & 736 \\
\hline 0.41 & 453 & 187 & 983 & 771 & 998 & 756 \\
\hline 0.43 & 431 & 187 & 983 & 789 & 998 & 774 \\
\hline 0.45 & 415 & 187 & 983 & 802 & 998 & 788 \\
\hline
\end{tabular}

\subsection{Compression Testing}

The compressive strength of the specimens were determined at 7 days, 28 days and 42 days using an ELE Compression strength Tester as stipulated in ASTM C39 / C39M - 15 [33].

\subsection{Setting Times}

The initial set and the final set times of cement mixed with fresh water and brackish water were determined via Vicat needle in accordance with ASTM C191-01 [34]

\section{Results and Discussion}

\subsection{Testing of the Aggregate}

\subsubsection{Organic Content}

The organic content of both the concreting sand and the beach sand were in the colour range 1 and 2 respectively. This falls within the acceptable range of 1 to 3 , indicating that beach sand is suitable as a fine aggregate based on its organic content.

\subsubsection{Sieve Analysis}

The well graded coarse aggregate and concreting were supplied by a Ready-mix concrete company in Trinidad, and as such met the necessary ASTM criteria. The fineness modulus of the concreting sand was 2.7 whilst the natural fineness modulus of the beach sand was 1.9. This was too low for use with ACI 211.1, and had to be separate and reconstituted to a fineness modulus of 2.6.

\subsection{Testing of the Water}

Brackish was of 5.65ppt salinity was obtained from under the bridge that crosses the Salybia river. Such a salinity falls within the range 0.5 and $35 \mathrm{ppt}$ for brackish water. Table 3.1 below presents the data for the chemical analysis of both the fresh water and the brackish water used. It can be seen that the brackish water has approximately 10 times more sulphates and 4 times more sodium ion content than fresh water. The potassium and magnesium ions content are similar for both the fresh water and the brackish water, with the brackish water having a slightly lower concentration of these ions. The data suggests that the majority of the sulphates present are associated with sodium ions as the potassium and magnesium concentrations are comparably small. 
Table 3.1. Chemical analysis comparing fresh water to brackish water

\begin{tabular}{|l|l|l|l|l|}
\hline Ions & $\begin{array}{l}\text { Sulphates } \\
\left(\mathrm{SO}_{4}\right)^{2-}\end{array}$ & $\begin{array}{l}\text { Sodium } \\
(\mathrm{Na})\end{array}$ & $\begin{array}{l}\text { Potassium } \\
(\mathrm{K})\end{array}$ & $\begin{array}{l}\text { Magnesium } \\
(\mathrm{Mg})\end{array}$ \\
\hline Fresh Water(ppm) & 8 & 26 & 6 & 6 \\
\hline Brackish Water(ppm) & 79 & 106 & 5 & 5 \\
\hline
\end{tabular}

\subsection{Concrete Mix Design}

From Table 2.2 above, it should be noted that the water content and the coarse aggregate content remained constant with changing water to cement ratio. This is because free water content determines slump, which was set at $75 \mathrm{~mm}$ to $100 \mathrm{~mm}$, and the proportion of coarse aggregate used is affected by fineness modulus. The difference in fineness modulus between the concreting sand and the beach sand resulted in the difference in the coarse aggregate content between those batches. The fine aggregate content increased as water to cement ratio increased. The increased fine aggregate content contributes to maintaining the volume of mortar as the amount of cement is reduced.

The water to cement ratio for concrete exposed to sea water is set between 0.40 and 0.45 by ACI 211.1-91 specifically to protect the embedded steel reinforcement. However, it is accepted that lower water to cement ratios produce higher quality concrete, with lower gel porosity and less capillary pores, resulting in a concrete with low permeability and high durability.

\subsection{Compression Testing}

From Figure 3.1, the CFF series generally produced the highest 7-day strength, with CFF37 producing the highest strength of $38.7 \mathrm{MPa}$. BBB41 returned the lowest 7-day strength amongst the batches at 20.4 MPa. The general trend is towards a reduction in strength with increasing water to cement ratio as expected.

Figure 3.2 presents the 28-day compressive strength of twenty of the batches of specimens produced. The BBB37 batch produced the highest 28-day compressive strength at $40.4 \mathrm{MPa}$. BBB41 yielded the lowest strength of 24.9MPa. The BBB, BFB, and CBB series exhibited very similar trends, whilst the CFF series showed the least variations in strength with water to cement ratio. The majority of batches did not meet the 28-day design strength as prescribed for a target mean strength. The exceptions were BFB43, tested at $39.6 \mathrm{MPa}$ and designed at $39 \mathrm{MPa}$ and $\mathrm{BFB} 43$, designed at $39 \mathrm{MPa}$ and tested at $39.6 \mathrm{MPa}$. Considering concrete industry practice, the characteristic strength for $5 \%$ defects at a standard deviation of $4 \mathrm{MPa}$, is about $5.6 \mathrm{MPa}$ less than the target mean strength [35]. Table 3.2 summarizes the results of the tested 28-day compressive strength, the target mean strength and the characteristic strength, indicating those batches that either met or failed to meet the criterion.

The 42-day strength of the batches is depicted in Figure 3.3. As with the previous tests, strength reduced with increasing water to cement ratio and in general, strength increased over the 28-day values. Additionally, the majority of batches reached the 28 -day characteristic strength by this point.

Two (2) batches of concrete CFF37 and CFF45 were cured in fresh water. A comparison of the compressive strengths obtained at 7, 28, and 42 days with CFB37 and CFB45 are shown in Tables 3.3 to 3.5. These $\mathrm{CF}$ batches are identically proportioned at the respective water to cement ratio, 
but cured in either fresh or brackish water. The brackish water has proven to be relatively benign to the concrete thus produced and seems to induce better strength.

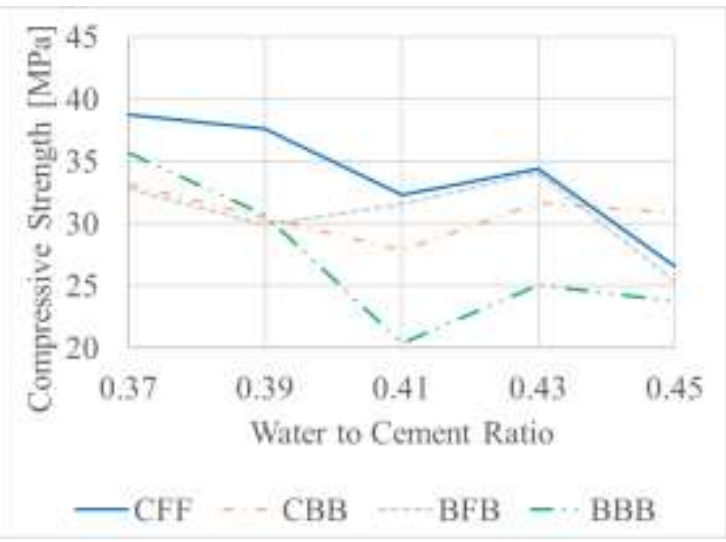

Figure 3.1. Graph of compressive strength vs water to cement ratio after 7-days

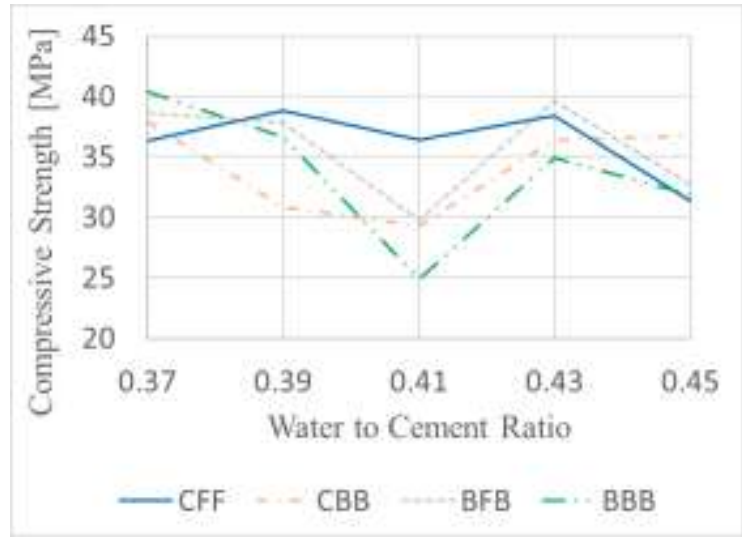

Figure 3.2. Graph of compressive strength vs water to cement ratio after 28-days

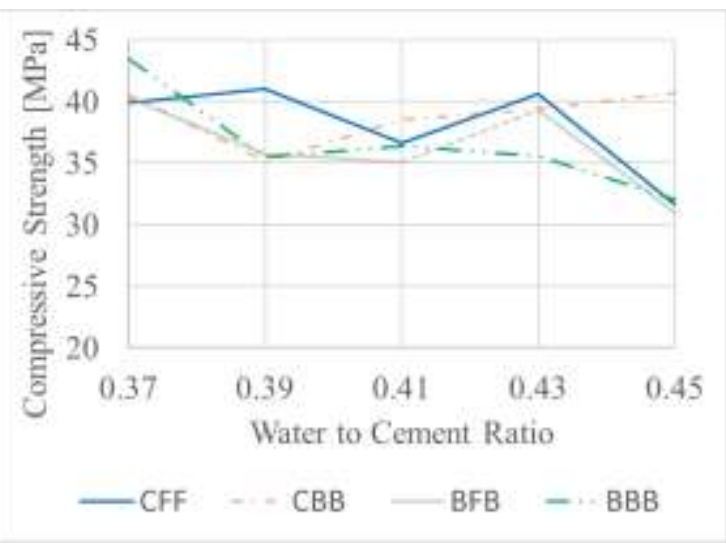

Figure 3.3. Graph of compressive strength vs water to cement ratio after 42-day 
Table 3.2. Tested strength vs target mean strength and characteristic strength of the batches of concrete produced

\begin{tabular}{|c|c|c|c|c|}
\hline $\begin{array}{l}\text { Batch } \\
\text { Designation }\end{array}$ & $\begin{array}{l}\text { Target Mean Strength } \\
(\mathrm{MPa})\end{array}$ & $\begin{array}{l}\text { Tested } \\
\text { Strength (MPa) }\end{array}$ & $\begin{array}{l}\text { Characteristic } \\
\text { Strength (MPa) }\end{array}$ & $\begin{array}{l}\text { Pass / } \\
\text { Fail }\end{array}$ \\
\hline BBB37 & \multirow[t]{5}{*}{ 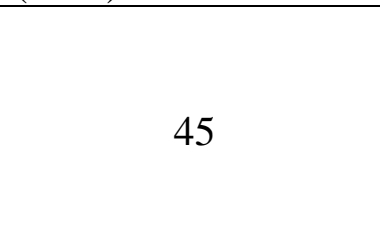 } & 40.39 & \multirow{5}{*}{39.36} & Pass \\
\hline BFB37 & & 38.64 & & Fail \\
\hline CBB37 & & 36.75 & & Fail \\
\hline CFB37 & & 44.81 & & Pass \\
\hline CFF37 & & 36.34 & & Fail \\
\hline BBB39 & \multirow{4}{*}{43} & 36.66 & \multirow{4}{*}{37.36} & Fail \\
\hline BFB39 & & 37.78 & & Pass \\
\hline CBB39 & & 36.40 & & Fail \\
\hline CFF39 & & 38.80 & & Pass \\
\hline BBB41 & \multirow{4}{*}{41} & 24.86 & \multirow{4}{*}{35.36} & Fail \\
\hline BFB41 & & 29.82 & & Fail \\
\hline CBB41 & & 29.30 & & Fail \\
\hline CFF41 & & 36.42 & & Pass \\
\hline BBB43 & \multirow{4}{*}{39} & 34.90 & \multirow{4}{*}{33.36} & Pass \\
\hline BFB43 & & 39.60 & & Pass \\
\hline CBB43 & & 30.89 & & Fail \\
\hline CFF43 & & 38.41 & & Pass \\
\hline BBB45 & \multirow{5}{*}{37.5} & 31.83 & \multirow{5}{*}{31.86} & Fail \\
\hline BFB45 & & 32.65 & & Pass \\
\hline CBB45 & & 37.89 & & Pass \\
\hline CFB45 & & 40.88 & & Pass \\
\hline CFF45 & & 31.33 & & Fail \\
\hline
\end{tabular}

Table 3.3 Compressive strength data for specimens produced from concreting sand and fresh water and cured in fresh water or brackish water for 7-days

\begin{tabular}{|c|c|c|c|c|c|}
\hline $\begin{array}{c}\text { Water to cement } \\
\text { ratio by mass }\end{array}$ & $\begin{array}{c}\text { Designed } \\
\text { Compressive } \\
\text { Strength (MPa) }\end{array}$ & Designation & \multicolumn{2}{|c|}{$\begin{array}{c}\text { Tested } \\
\text { Compressive } \\
\text { Strength (MPa) }\end{array}$} & Designation \\
\hline 0.37 & 45.0 & CFF37 $\rightarrow$ & 38.7 & 34.87 & $\longleftarrow$ CFB37 \\
\hline 0.45 & 37.5 & CFF45 $\rightarrow$ & 26.6 & 33.8 & $\leftarrow$ CFB45 \\
\hline
\end{tabular}

Table 3.4 Compressive strength data for specimens produced from concreting sand and fresh water and cured in fresh water or brackish water for 28-days

\begin{tabular}{|c|c|c|c|c|c|}
\hline $\begin{array}{c}\text { Water to cement } \\
\text { ratio by mass }\end{array}$ & $\begin{array}{c}\text { Designed } \\
\text { Compressive } \\
\text { Strength (MPa) }\end{array}$ & Designation & \multicolumn{2}{|c|}{$\begin{array}{c}\text { Tested } \\
\text { Compressive } \\
\text { Strength (MPa) }\end{array}$} & Designation \\
\hline 0.37 & 45.0 & CFF37 $\rightarrow$ & 36.34 & 44.81 & $\longleftarrow$ CFB37 \\
\hline 0.45 & 37.5 & CFF45 $\rightarrow$ & 31.33 & 40.88 & $\leftarrow$ CFB45 \\
\hline
\end{tabular}


Table 3.5 Compressive strength data for specimens produced from concreting sand and fresh water and cured in fresh water or brackish water for 42-days

\begin{tabular}{|c|c|c|c|c|c|}
\hline $\begin{array}{c}\text { Water to cement } \\
\text { ratio by mass }\end{array}$ & $\begin{array}{c}\text { Designed } \\
\text { Compressive } \\
\text { Strength (MPa) }\end{array}$ & Designation & \multicolumn{2}{|c|}{$\begin{array}{c}\text { Tested } \\
\text { Compressive } \\
\text { Strength (MPa) }\end{array}$} & Designation \\
\hline 0.37 & 45.0 & CFF37 $\rightarrow$ & 39.89 & 46.14 & $\leftarrow$ CFB37 \\
\hline 0.45 & 37.5 & CFF45 $\rightarrow$ & 31.63 & 43.24 & $\leftarrow$ CFB45 \\
\hline
\end{tabular}

Further analysis of Figures 3.1 to 3.3 reveals the variation of compressive strength with water to cement ratio for each of the batch series produced at 7-days, 28-days and 42-days. The concrete produced with and cured in brackish water experienced strength gains between 28-days and 42days, whereas concrete produced with beach sand and fresh water and cured in brackish water did not. This was probably due to he tconcrete perferming better when cured with lower osmotic gradients.

\subsection{Setting Times}

The initial setting time of the cement was not significantly affected by the type of water, as the brackish water produced slightly faster setting time of 120 minutes versus 125 minutes; a variation of $4 \%$. For the final setting time, the fresh water produced a slightly quicker setting time of 200 minutes versus 205 minutes for the brackish water, a $2 \%$ increase. Thus, there is no significant acceleration or retardation of the setting process by the brackish water.

Table 3.6. Vicat Needle Setting Times for cement mixed with Fresh Water and Cement mixed with brackish water

\begin{tabular}{|l|c|c|}
\hline & $\begin{array}{c}\text { Initial Set } \\
\text { Time (mins.) }\end{array}$ & $\begin{array}{c}\text { Final Set } \\
\text { Time (mins.) }\end{array}$ \\
\hline Fresh Water & 125 & 200 \\
\hline $\begin{array}{l}\text { Brackish } \\
\text { Water }\end{array}$ & 120 & 205 \\
\hline
\end{tabular}

\section{Conclusions and Recommendation}

Sand is becoming a scarce commodity globally due to demands from many sectors, including civil engineering, manufacturing and tourism. Consequently, new sources of this commodity must be discovered and evaluated for purpose. Beach sand as mined from the shoreline of Salybia Bay was not of the required fineness modulus for concrete, however, this was rectified by adjustments to the proportions from the relevant sieves used in the reconstituted sand. Mahendra et al. indicated that off-shore sand is a better alternative to beach sand, used in the building construction industry [21]. The data revealed that beach sand is capable of producing concrete with fresh of brackish water, but has better results with the brackish water.

In Trinidad and Tobago, it is illegal to mine beach sand, however, for coastal projects where beach sand must be excavated, its utilization in concrete can be considered. 
Climate and population growth have exhorted significant pressures on potable water supplies. The financial and environmental cost of desalinations must also be considered when solutions are being sought. Concrete as a construction material utilizes significant quantities of water globally, and as such, exploration of non-traditional supplies of water must be considered. Brackish water has been found to be suitable for curing concrete produced with traditional ingredients as well as concrete produced with brackish water and beach sand. The results suggest that it produces stronger traditional concrete than fresh water.

Further investigations, over longer periods of time are necessary to understand the long-term implications of material substitution on the durability of the concrete produced. Additionally, incorporation of and exposure to seawater must be investigated. 


\section{References}

[1] CHATHAM HOUSE REPORT Making Concrete Change: Innovation in Low-carbon Cement and Concrete 13 June 2018, Johanna Lehne, Felix Preston.

[2] NRMCA Publication Number 2PCO2 Concrete $\mathrm{CO}_{2}$ Fact Sheet June 2008.

[3] Climatewire CLIMATE Cement Producers Are Developing a Plan to Reduce $\mathrm{CO}_{2}$ Emissions By Chelsea Harvey, E\&E News on July 9, 2018.

[4] https://telanganatoday.com/cement-industry-reducing-carbon-footprint. Accessed 08/12/2019. [5] J. A. SANDOVAL MORFIN, R. RAMIREZ JIMÉNEZ. 2017. Analysis of physical and mechanical properties of Concrete Blocks using seawater for manufacturing. In 13th International congress of Engineering Autonomous University of Queretaro.

[6] P. K. Cornejo, M. V. E. Santana, D. R. Hokanson, J. R. Mihelcic, Q. Zhang. Carbon footprint of water reuse and desalination: a review of greenhouse gas emissions and estimation tools. Journal of Water Reuse and Desalination. 4 no. 4, (2014), 238-252.

[7] ] M. K. Boodhan, Renewable energy powered desalination in SIDS- opportunities and challenges in the Caribbean Region.

[8] K. Zaher, S. Shihada, 2003. Effect of Gaza seawater on concrete strength for different exposures. Journal of the Islamic University of Gaza, 11 No. 20, (2003), 156-172.

[9] A. M. Neville, J. J. Brooks, 1994. Concrete technology. Longman Scientific and Technical. [10] N. Buenfeld, J. B. Newman. The permeability of concrete in a marine environment. Magazine of Concrete Research, 36 No. 127,(1984), 67-80.

[11] W.C. Hansen, Twenty-year report on long-time study of cement performance in concrete, Research Department Belletin 175, Portland Cement association, Research and Development Laboratories, Skokie, May 1965.

[12] R. N. Swamy, 1991. The alkali-silica reaction in concrete. Spon Press.

[13] P. Domone, J. M. Illston, 2010. Construction Materials Their nature and behaviour Fourth edition, Spon Press.

[14] Fiber-Reinforced Polymer Reinforcement, American Concrete Institute, Farmington Hills, MI, 2002, concrete.org. Accessed 08/12/2019.

[15] Mbadikea, A.U. Elinwab EFFECT OF SALT WATER IN THE PRODUCTION OF CONCRETE E.M. Nigerian Journal of Technology Vol. 30, No. 2, June 2011.

[16] H. Khan, T. Izhar, N. Mumtaz, A. Ahad. Effect of Saline Water in Mixing and Curing on Strength of Concrete. Internation Journal for Science and Advance Research In Technology, 2 no. 5, 2016.

[17] F. M. Wegian. Effect of seawater for mixing and curing on structural concrete, The IES Journal Part A: Civil \& Structural Engineering, 3 no. 4, (2010), 235-243, DOI: 10.1080/19373260.2010.521048.

[18] A. F. Olutoge, M. G. Amusan. The Effect of Sea Water on Compressive Strength of Concrete. International Journal of Engineering Science Invention. 3 no. 7 (2014), 23-31.

[19] Q. Li, H. Geng, Y. Huang, and Z. Shui, "Chloride resistance of concrete with metakaolin addition and seawater mixing: A comparative study," Constr. Build. Materials 101, (2015), 184192.

[20] O.O. Akinkurolere, Cangru Jiang and O.M. Shobola. The Influence of Salt Water on the Compressive Strength of Concrete. Journal of Engineering and Applied Sciences, 2, (2007), 412415. 
[21] R. Mahendran, K. Godwin, T. Gnana Selvan and M. Murugan. EXPERIMENTAL STUDY ON CONCRETE USING SEA SAND AS FINE AGGREGATE. International Journal of Scientific \& Engineering Research, 7 no. 5, (2016) 49-52.

[22] D. A. R. Dolage1, M. G. S. Dias and C. T. Ariyawansa, 2013. Offshore Sand as a Fine Aggregate for Concrete Production. British Journal of Applied Science \& Technology, 3(4): 813825.

[23] British Standards Institution. (1992). SPECIFICATION FOR AGGREGATES FROM NATURAL SOURCES FOR CONCRETE (BS 882 : 1992) Retrieved from https://www.saiglobal.com/ .

[24] (c) FAO 1-2019. Fishery and Aquaculture Country Profiles. Trinidad and Tobago (2018). Country Profile Fact Sheets. In: FAO Fisheries and Aquaculture Department [online]. Rome. Updated 0105 2018. [Cited 30 December 2019]. http://www.fao.org/fishery/.

[25] ASTM C40/C40M-16, Standard Test Method For Organic Impurities In Fine Aggregates For Concrete, ASTM International, West Conshohocken, PA, 2016, www.astm.org.

[26] ASTM C136 / C136M - 14, Standard Test Method for Sieve Analysis of Fine and Coarse Aggregates, ASTM International, West Conshohocken, PA, 2014, www.astm.org.

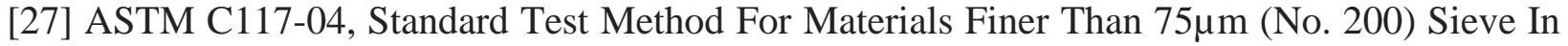
Mineral Aggregates By Washing, ASTM International, West Conshohocken, PA, 2004, www.astm.org.

[28] ASTM C33 / C33M - 18, Standard Specification for Concrete Aggregates, ASTM International, West Conshohocken, PA, 2018, www.astm.org.

[29] ASTM D516-16, Standard Test Method for Sulfate Ion in Water, ASTM International, West Conshohocken, PA, 2016, www.astm.org.

[30] ASTM D3561-16, Standard Test Method for Lithium, Potassium, and Sodium Ions in Brackish Water, Seawater, and Brines by Atomic Absorption Spectrophotometry, ASTM International, West Conshohocken, PA, 2016, www.astm.org.

[31] ASTM D511-14, Standard Test Methods for Calcium and Magnesium in Water, ASTM International, West Conshohocken, PA, 2014, www.astm.org.

[32] ACI 211.1-91, Standard Practice for Selecting Proportions for Normal, Heavyweight, and Mass Concrete American Concrete Institute, Farmington Hills, MI, 2002, concrete.org.

[33] ASTM C39 / C39M, Standard Test Method for Compressive Strength of Cylindrical Concrete Specimens, ASTM International, West Conshohocken, PA, 2014, www.astm.org.

[34] ASTM C191-01, Standard Test Method for Time of Setting of Hydraulic Cement by Vicat Needle, ASTM International, West Conshohocken, PA, 2001, www.astm.org.

[35] D.C. Teychenné, R.E. Franklin, H.C. Erntroy, 1997. Design of Normal Concrete Mixes. Construction Research Communications Ltd. 